\title{
Prevention of Gastrointestinal Pathologies: Comparative Study of the Microbial Flora of the Sanitary Surfaces of the Toilets of Students and Staff of the Félix Houphouët-Boigny University
}

\author{
N'gbesso Jean-Paul N'gbesso1, Beudje Félicité2, Okoubo Née A. Nicaise N'guessan1, \\ Mambey Serge ${ }^{3}$, Juili Landry A. Arra ${ }^{4}$, Allou Aime Constantin Ahoua ${ }^{5}$
}

\begin{abstract}
${ }^{1}$ Biology and Health Laboratory, UFR Environment, Vectors and Parasites Université Félix Houphouët-Boigny, Abidjan, Côte d'Ivoire

${ }^{2}$ National Laboratory for Agricultural Development Support (LANADA)/Bacteriology Service, Abidjan, Côte d'Ivoire

${ }^{3}$ Direction de l'Hygiène Publique et de Santé Environnement (DHPSE), Abidjan, Côte d'Ivoire

${ }^{4}$ University Center for Research and Application in Remote Sensing, Félix Houphouët-Boigny University, Abidjan, Côte d'Ivoire ${ }^{5}$ Institute of Tropical Geography, Félix Houphouët-Boigny University, Abidjan, Côte d'Ivoire

Email: ngbessongbessojeanpaul@gmail.com
\end{abstract}

How to cite this paper: N'gbesso, N.J.-P., Félicité, B., N'guessan, O.N.A.N., Serge, M., Arra, J.L.A. and Ahoua, A.A.C. (2020) Prevention of Gastrointestinal Pathologies: Comparative Study of the Microbial Flora of the Sanitary Surfaces of the Toilets of Students and Staff of the Félix Houphouët-Boigny University. Open Journal of Medical Microbiology, 10, 129-138.

https://doi.org/10.4236/ojmm.2020.103011

Received: February 7, 2020

Accepted: August 17, 2020

Published: August 20, 2020

Copyright $\odot 2020$ by author(s) and Scientific Research Publishing Inc. This work is licensed under the Creative Commons Attribution International License (CC BY 4.0).

http://creativecommons.org/licenses/by/4.0/ (c) (i) Open Access

\begin{abstract}
Pathologies transmissible by hand such as gastrointestinal pathologies constitute a real public health problem, especially in sub-Saharan Africa where hygienic conditions are precarious. This study took place at Félix Houphouët-Boigny University from April to August 2018. The samples were taken from toilet surfaces such as doorknobs, tap heads, flush push buttons and seats WC. A total of three hundred and sixty-eight (368) samples were obtained, including 170 from the staff toilets and 198 from the student toilets. The results revealed the presence of total coliforms, Escherichia spp and Salmonella spp. The surfaces of student toilets were the most contaminated surfaces. The presence of entero-bacteria on the contact surfaces of the toilets of the Félix Houphouët-Boigny university represents a health risk for the university population.
\end{abstract}

\section{Keywords}

Communicable Diseases, Hand, Hygiene, Enterobacteriaceae, Toilet, University 


\section{Introduction}

In the world, Hygiene has been a major issue since antiquity as evidenced by the mobilization of the international community for its promotion [1]. Lack of hygiene is the basis of manual pathologies such as gastro pathologies-intestinal which constitute a real public health problem worldwide [1].

In sub-Saharan Africa, gastrointestinal pathologies also represent a major public health problem mainly in environments with poor hygienic conditions [2]. Today, it is estimated at more than 2.5 billion people worldwide, including 550 million in sub-Saharan Africa who do not have minimum hygiene conditions, according to the recent report of the joint WHO/UNICEF program on water, Hygiene and Sanitation (EHA) [3] [4] [5]. Human health risks are undoubtedly the most serious and widespread problem. Each year, around 3.5 million people die from manual diseases, especially in developing countries [6] [7]. The organization of several forums on Water, Hygiene and Sanitation (WASH) (Marrakech in 1997, The Hague in 2000, Kyoto in 2003, Mexico in 2006 and Senegal in 2012) testifies to the magnitude of this problem in developing countries [8]. In these countries, poor hygiene and a lack of basic sanitation are the foundations of these numerous manual pathologies [3] [4] [9] [10]. The latter are themselves the causes of absenteeism from school and work, and therefore from a low level of education and significant economic and income losses across a developing country [3] [11]. They represent a huge burden for these countries [12] [13]. Indeed, the physical environment and the degree of cleanliness of WAH works have an impact on the health and well-being of learners. In the event that this environment does not have acceptable sanitation and hygiene conditions such as hand washing facilities and toilets in good condition, the diseases develop and spread quickly. It becomes a high-risk space for the latter by accentuating their vulnerability to manual illnesses, especially gastrointestinal [14]. However, the provision of hygiene and sanitation facilities could reduce these manual diseases by almost $90 \%$ [15] [16] [17].

In Côte d'Ivoire, the level of hygiene and sanitation is still low despite the establishment of a policy to improve the living conditions and well-being of the populations [18].

This low level of hygiene recorded among students at the Félix HouphouëtBoigny University of Côte d'Ivoire [19] [20] and the promiscuity observed led to a study whose objective was to determine the microbial ecology of the germs present in the sanitary surfaces of university toilets. We thought it appropriate to assess microbial germs by emphasizing those capable of transmitting gastrointestinal infections in the sanitary toilets of students and staff of the Félix Houphouët-Boigny University.

\section{Study Area}

The study was carried out in the toilets of students and staff at the Félix Houphouët-Boigny University in Cocody (Abidjan, Côte d'Ivoire). It is located 
between $5^{\circ} 20$ and $5^{\circ} 38$ north latitude and $3^{\circ} 58$ and $3^{\circ} 59$ west longitude (Figure $1)$. It is the main University of Côte d'Ivoire. To date, it has received more than 60,000 students [21].

\section{Methodology}

\subsection{Data Collection Methodology Sample Collection and Analysis}

A quantitative and qualitative microbiological control study was carried out from April to August 2018 at the Félix Houphouët-Boigny University. Sampling was carried out at 184 functional toilets out of a total of 340 university toilets. It made it possible to count 368 contact surfaces including 80 door handles, 84 tap heads, 90 push buttons and 114 WC seats. The swab method [22] was used on surfaces such as toilet door handles, faucet heads, flush buttons and toilet seats. Sterile swabs were previously moistened in sterile peptone water contained in a tube. For each surface, the swab was passed over areas defined in narrow parallel ridges by rotating them slightly, then over the same areas in perpendicular ridges. The swab was then placed in the same tube containing sterile peptone water. The tube is identified and placed in a cooler containing cooling pack to maintain a temperature of $4^{\circ} \mathrm{C}$ during transport to the laboratory. The content of each tube was homogenized by gentle manual stirring before being sown on several agars depending on the bacteria sought.

- Salmonella spp was sought according to the three stages described by ISO 6578 [23] and the confirmation of the strains was carried out thanks to biochemical tests (search for: gelatinase, production of indole, production of $\mathrm{H} 2 \mathrm{~S}$, decarboxylase, deaminases and urease)

- Isolation of the Escherichia spp strains was carried out on lactose deoxycholate agar and the confirmation of the strains was carried out by biochemical tests.

- The identification of Pseudomonas spp was carried out by the search for greenish colonies, then oxidase tests were carried out using oxidase disks and confirmation of the strains was carried out using biochemical tests.

The search and identification of total coliforms, Escherichia spp, Salmonella spp and Pseudomonas spp were carried out according to classical microbiology.

\subsection{Data Processing and Analysis}

Data entry was carried out with Excel software. The chi-square test was used to compare values of the proportions of the germs. Interpretations are based on the p-value in a $95 \%$ confidence interval (CI). The digital locality map was produced with ArcGIS software.

\section{Results}

\subsection{Sample Size}

The microbiological analysis was carried out on 368 composite samples, including 170 in the staff washroom and 198 in the student washroom (Table 1). 


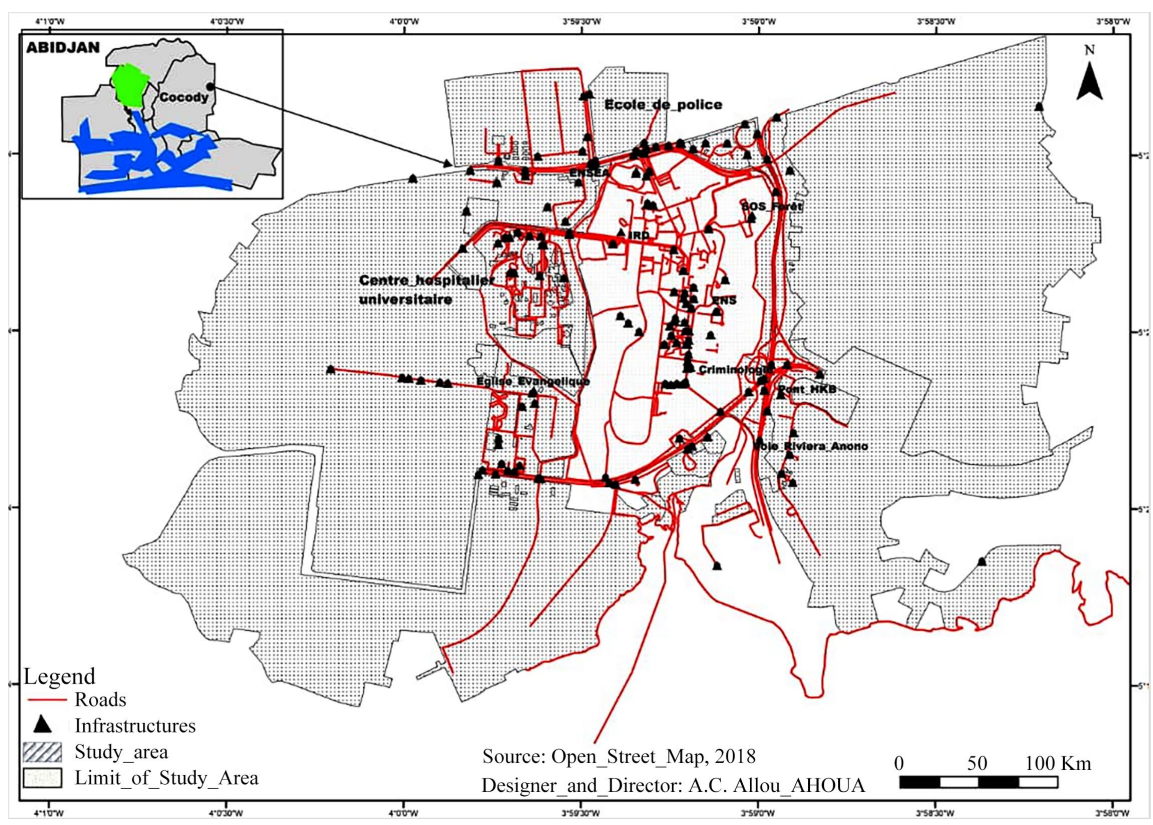

Figure 1. Study area.

Table 1. Composition of the sample size.

\begin{tabular}{ccccc}
\hline \multirow{2}{*}{ Indications } & \multicolumn{2}{c}{ Staff } & \multicolumn{2}{c}{ Student } \\
\cline { 2 - 5 } & $\mathbf{n}$ & Percentage (\%) & $\mathbf{n}$ & Percentage (\%) \\
\hline Door handles & 36 & 21.18 & 44 & 22.22 \\
Tap head & 44 & 25.88 & 40 & 20.20 \\
WC push button & 40 & 23.53 & 50 & 25.25 \\
WC seat & 50 & 29.41 & 64 & 32.32 \\
Total & 170 & 100 & 198 & 100 \\
\hline
\end{tabular}

\subsection{Staff Toilet Results}

The overall proportions are $21.17 \%$ for total coliforms, the same for Escherichia spp, $1.17 \%$ for Salmonella spp. No Pseudomonas spp has been identified (Table 2). Escherichia spp is the most obtained genus with a proportion of $26 \%$ WC seats are the most contaminated areas.

\subsection{Results from Student Toilets}

The overall proportions are $51.51 \%$ for total coliforms, the same for Escherichia spp, $4.54 \%$ for Salmonella spp (Table 3). No Pseudomonas spp has been identified. Escherichia spp and Salmonella spp is the most obtained genus with a proportion of $78.12 \%$ and $14.06 \%$ respectively. WC seats are the most contaminated areas.

\subsection{Comparison of Bacterial Flora in Toilets}

The main germs such as total coliforms, Escherichia spp and Salmonella spp are abundant on the surface of student toilets. No Pseudomonas were observed in 
the different toilets. The proportions of Escherichia spp are 13.63\% and $8.33 \%$ respectively at the door handles of students and staff. No statistically significant difference was obtained between these proportions of Escherichia spp at the door handles $(\mathrm{X}=0.65 ; \mathrm{p}$-value $=0.4187)$. At the level of the tap heads, proportions of Escherichia spp were 55\% and $20.45 \%$ respectively at the level of the student and staff toilets. A statistically significant difference was observed between the proportions of Escherichia spp obtained at the tap heads $(\mathrm{X}=11.14$; p-value $=0.0008)$. A proportion of $48 \%$ of Escherichia spp was obtained at the level of the push buttons in the student toilets against $27.5 \%$ at that of the staff. We noted a statistically significant difference in these proportions $(\mathrm{X}=3.77 ; \mathrm{X}=$ 0.05). The WC seats, on the other hand, presented the strongest contamination. A proportion of $14.06 \%$ of Escherichia spp was obtained at the level of the staff toilets against $78.12 \%$ at the level of the students' toilets. A statistically difference was obtained between the proportion of Escherichia spp at the level of the seats of the student and staff toilets $(\mathrm{X}=30.59$; $\mathrm{p}$-value $=0.001)$. Salmonella spp proportions of $14.06 \%$ and $4 \%$ respectively were obtained at the level of the student and staff WC seats (Figure 2). No statistically significant difference was obtained between these values $(\mathrm{X}=4.05$; $\mathrm{p}$-value $=0.44)$.

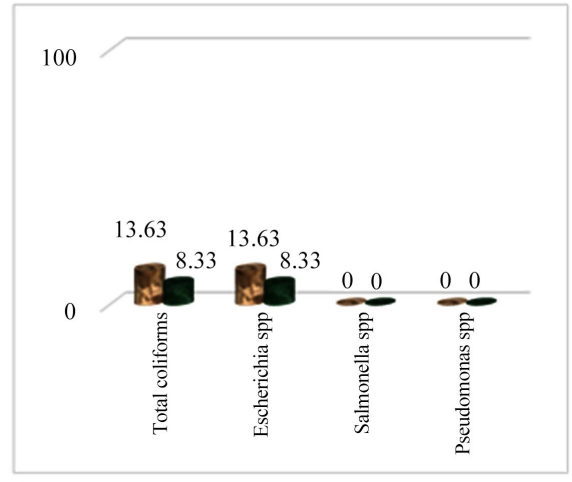

(a) Toilet door handles

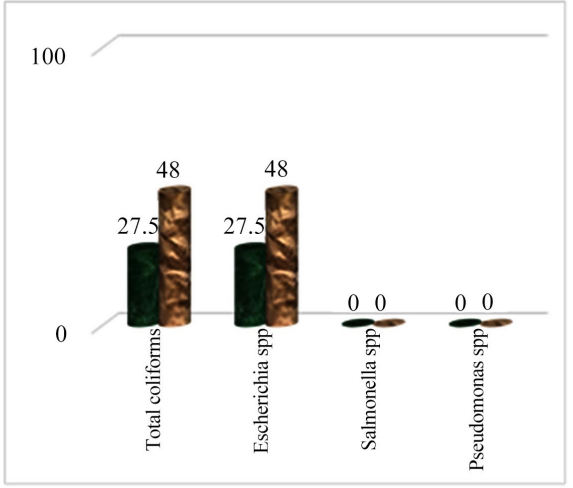

(c) Toilet push buttons

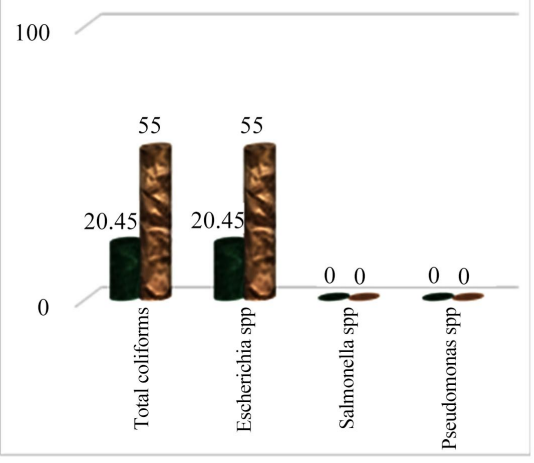

(b) Toilet tap head

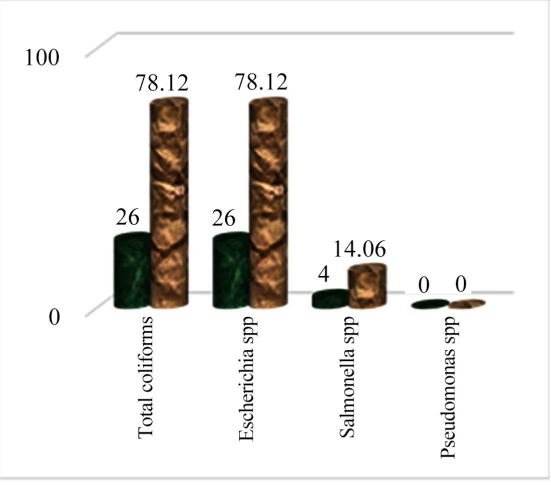

(d) Toilet WC seat

Staff toilet areas

Student toilet areas

Figure 2. Comparison of germs on student and staff washroom surfaces. 
Table 2. Proportion of germs sought according to the swabbed surfaces of the staff.

\begin{tabular}{ccccc}
\hline \multirow{2}{*}{ Indications } & \multicolumn{4}{c}{ Bacteria sought $\mathrm{n}(\%)$} \\
\cline { 2 - 5 } & $\begin{array}{c}\text { Total } \\
\text { coliforms }\end{array}$ & $\begin{array}{c}\text { Escherichia } \\
\text { spp }\end{array}$ & $\begin{array}{c}\text { Salmonella } \\
\text { spp }\end{array}$ & $\begin{array}{c}\text { Pseudomonas } \\
\text { spp }\end{array}$ \\
\hline Door handles $(\mathrm{n}=\mathbf{3 6})$ & $3(8.33)$ & $3(8.33)$ & $0(0)$ & $0(0)$ \\
Tap head $(\mathrm{n}=\mathbf{4 4})$ & $9(20.45)$ & $9(20.45)$ & $0(0)$ & $0(0)$ \\
WC push button $(\mathrm{n}=40)$ & $11(27.5)$ & $11(27.5)$ & $0(0)$ & $0(0)$ \\
WC seat $(\mathrm{n}=\mathbf{5 0})$ & $13(26)$ & $13(26)$ & $2(4)$ & $0(0)$ \\
Total & $36(21.17)$ & $36(21.27)$ & $2(1.17)$ & $\mathbf{0}(0)$ \\
\hline
\end{tabular}

Table 3. Proportion of germs sought according to surface area squirmed in student toilets.

\begin{tabular}{ccccc}
\hline & \multicolumn{4}{c}{ Bacteria sought: $\mathbf{n}(\%)$} \\
Indications & $\begin{array}{c}\text { Total } \\
\text { coliforms }\end{array}$ & $\begin{array}{c}\text { Escherichia } \\
\text { spp }\end{array}$ & $\begin{array}{c}\text { Salmonella } \\
\text { spp }\end{array}$ & $\begin{array}{c}\text { Pseudomonas } \\
\text { spp }\end{array}$ \\
\hline Door handles $(\mathrm{n}=44)$ & $6(13.63)$ & $6(13.63)$ & $0(0)$ & $0(0)$ \\
Tap head $(\mathrm{n}=\mathbf{4 0})$ & $22(55)$ & $22(55)$ & $0(0)$ & $0(0)$ \\
WC push button $(\mathrm{n}=\mathbf{5 0})$ & $24(48)$ & $24(48)$ & $0(0)$ & $0(0)$ \\
WC seat $\mathbf{n}=\mathbf{6 4}$ & $50(78.12)$ & $50(78.12)$ & $9(14.06)$ & $0(0)$ \\
Total & $\mathbf{1 0 2 ( 5 1 . 5 1 )}$ & $102(51.51)$ & $\mathbf{9 ( 4 . 5 4 )}$ & $\mathbf{0 ( 0 )}$
\end{tabular}

\section{Discussion}

This study highlighted the presence of total coliforms, Escherichia spp and Salmonella spp at the Félix Houphouët-Boigny university. The overall proportions are $21.27 \%$ for Escherichia spp, and $1.17 \%$ for Salmonella spp at the level of the staff toilets. On the other hand, the overall proportions are 51.51\% for Escherichia spp, and $4.54 \%$ for Salmonella spp at the level of the staff toilets. However, the absence of Pseudomonas spp has been reported.

The results showed that the university environment of toilets has potentially pathogenic microorganisms. These results are corroborated with the studies of Rutala and collaborators on the one hand, and of Weber and collaborators on the other hand. Indeed, according to these authors, the human environment is largely contaminated by specifically environmental microorganisms [22] [23]. This contamination varies qualitatively and quantitatively over time. They also demonstrated that the capacity to create an infection results from a combination of factors associating the level of expression of the virulence factors of the microorganism, its quantity or its concentration, the mode of contamination and the receptivity of the host.

The contact surfaces of the hands in the toilets presented a bacterial flora in particular enterobacteria. These results are in agreement with that of Munoz and collaborators who have demonstrated the presence of bacteria at the contact surfaces of door handles in a university health center [24]. 
According to our results, the microbial flora detected at our study site consists of the genera Escherichia and Salmonella. It should be noted that this flora found on surfaces depends on several factors such as human activity which leads to an intake of microorganisms. Without effective bio-cleaning, the survival of these microorganisms on surfaces can be very prolonged. Escherichia spp bacteria can survive for 1.5 hours to 16 months on dry, inert surfaces [25]. In addition to the quality of the bio-cleaning, surface contamination depends on many factors linked to the microorganism: its life on an inert support (which varies depending on the material, temperature, drying), its adhesion to the surface, its ability to produce a biofilm and its ability to withstand adverse conditions [26] [27].

In our study, the genus Escherichia occupied the first place of enterobacteria. This abundance could be explained by their predominance in the optional aerobic-anaerobic flora of the digestive tract in humans and in many animal species on the one hand, and on the other hand by their undemanding living conditions [28] [29]. It has been noted that Escherichia spp is responsible for the most common in especially nosocomial infections and is much less resistant to desiccation [27] [30]. The absence of the genus Pseudomonas could be due to the method of analysis which is likely to be poorly suited to these. The microorganisms of human origin or specifically environmental present in the environment belong to opportunistic species and to pathogenic species for humans. It should be noted that most infections linked to environmental contamination are still poorly documented, with the exception of those linked to some microorganisms of environmental origin [31] [32] [33].

Controlled epidemiological studies show an association between infection and exposure to a contaminated environment is still rare [34] [35] [36] [37].

The most contaminated sites were the toilet seats, the push buttons and the tap heads and taps. This situation is linked to the fact that these materials are frequently exposed to faeces. This observation is confirmed by Marty [38]. For this author, this significant colonization of sites constitutes a real risk of manual transmission of bacilli which can be the source of infection [28]. In order to reduce this manual transmission to the handles of hygienist authors like Séguier in Strasbourg, proposed the use of ULNA door handles.

Concerning isolated bacteria, a high proportion of Gram-negative bacilli is noted.

The presence of Escherichia spp coli, a witness to faecal contamination confirms poor hygiene in our university structure. If these germs present themselves as opportunistic agents for the sick, the strains of Salmonella spp isolated in the present study constitute a major infectious risk for the students and the staff of the Félix Houphouët-Boigny University because they are specific pathogenic bacteria.

The limits of this study could be located in the analysis of samples. This analysis focused more on classical microbiology. High proportions of bacteria could be obtained if one had to use culture media more specific to germs. 


\section{Conclusion}

The genera Escherichia spp and Salmonella spp are bacteria present on the contact surfaces of university surfaces of student toilets. The most abundant proportions were obtained in the area of student toilets (Escherichia spp: 51.51\% and Salmonella spp: $4.54 \%$ ). The most contaminated areas in order of abundance are toilet seats, push buttons; toilet tap heads and door handles. The presence of enterobacteria in the sanitary surfaces of the toilets of the Félix Houphouët-Boigny University represents a health risk for the university population. We recommend installing hand hygiene devices and regular cleaning of WASH sanitary facilities to limit the risk of faecal-oral contamination. The identification of the species of germs found and their resistance to different antibiotics will be the next step of the study.

\section{Acknowledgements}

Our thanks go to the heads of the training and research units, the heads of the cleaning service staff and the cleaning service staff of the Félix HouphouetBoigny University. We also thank the managers and the technicians of central and veterinary laboratory of Bingerville (LCVB) in particular Mr ELOI ADJE and Mrs Traore Mariana épse AKE.

\section{Conflicts of Interest}

The authors declare no conflicts of interest regarding the publication of this paper.

\section{References}

[1] SALABERT Delphine married Dubar (2008) State of Affairs in a Commune of High Breasts. Doctoral Thesis in Generalmedicine, Pierre and Marie Curie University, France, 122.

[2] Rindra, R. (2012) Environmental Impacts on Childhood Diarrhea in Madagascar: Campylobacter Risk Analysis. Doctoral Thesis in Medicine, University of Grenoble, France, 164.

[3] White Water (2010) For a Better Dissemination of Sanitation Works in Rural Sahel 80 Concrete Proposals-Synthesis of the Study, 20.

[4] Freeman, M.C., Clasen, T. and Dreibelbis, R. (2014) The Impact of a School-Based Water Supply and Treatment, Hygiene, and Sanitation Program on Pupil Diarrhoea: A Cluster Randomized Trial. Epidemiology and Infection, 142, 340-351. https://doi.org/10.1017/S0950268813001118

[5] WHO (2017) Water-Related Diseases. http://www.who.int/water_sanitation_health/diseases-risks/diseases/en

[6] WHO (2000) Global Water Supply and Sanitation Assessment 2000 Report.

[7] WHO (2015) Water, Sanitation and Hygiene to Accelerate and Sustain Progress in the Fight against Neglected Tropical Diseases. Global Strategy 2015-2020, 50.

[8] ANSD (2014) National Agency for Statistics and Demography Senegal: Demographic and Continuous Health Survey (EDS-Continue), 263.

[9] IFRCS (2007) International Federation of Red Cross and Red Crescent Societies. 
The International Federation Software Tools for Long-Term Water and Sanitation Programming, 52.

[10] Briscoe, J., Feachem R.G. and Rahaman, M.M. (1987) Health Effect Assessment: Water Supply, Sanitation and Hygiene. UNICEF, ICDDRB, CRDI (Center for Research for International Development), Ottawa, Canada, 86.

[11] Diallo, A.C. (2015) Evaluation of Hygienic Hand Washing Practices By Sampling, Sampling and Microbiological Analyzes: Case of Students and Staff of the University of Moncton, Moncton Campus. Master Thesis, Université de Moncton, Moncton, 118.

[12] Water (2011) Sanitation and Hygiene (WASH) in Schools. Manual for ChildFriendly Schools, UNICEF, 50.

[13] The PLoS Medicine Editors (2009) Clean Water Should Be Recognized as a Human Right. PLoS Medicine, 6, e1000102. https://doi.org/10.1371/journal.pmed.1000102

[14] Anonymous (2013) Access to Water and Sanitation in Schools in the Saint Louis Region/Senegal. UNICEF, 33.

[15] Fewtrell, L., Kaufmann, R.B., Kay, D., Enanoria, W. and Haller, L. (2005) Water, Sanitation, and Hygiene Interventions to Reduce Diarrhoea in Less Developed Countries: A Systematic Review and Meta-Analysis. The Lancet Infectious Diseases, 5, 42-52. https://doi.org/10.1016/S1473-3099(04)01253-8

[16] Gruber, J.S., Reygadas, F., Arnold, B.F., Ray, I. and Nelson, K. (2013) A Stepped Wedge, Cluster-Randomized Trial of a Household Uv-Disinfection and Safe Storage Drinking Water Intervention in Rural Baja California Sur, Mexico. The American Journal of Tropical Medicine and Hygiene, 89, 238-245. https://doi.org/10.4269/ajtmh.13-0017

[17] Strunz, E.C., Addiss, D.G., Stocks, M.E., Ogden, S. and Utzinger, J. (2014) Water, Sanitation, Hygiene, and Soil-Transmitted Helminth Infection: A Systematic Review and Meta-Analysis. PLoS Medicine, 11, e1001620. https://doi.org/10.1371/journal.pmed.1001620

[18] MSHP (2015) Diagnostic Study: National Strategy for Hygiene Promotion in Côte d'Ivoire 2016-2020, 187.

[19] Romaric, A. (2016) Evaluation of Hygienic Hand Washing Practices for Students of UFR Biosciencse, Félix Houphouet-Boigny University, Abidjan, 52.

[20] N'Gbesso, N.J.-P., N'Guessan, N.A., Brou, A.L., Alloka, J.-R., N’Dri, F.K. and Gnazale, G.R. (2017) Evaluation of Knowledge, Attitude and Practices in Hand Hygiene of Students in Biological Sciences from Felix Houphouët-Boigny University of Cocody (Abidjan-Côte d'Ivoire) International Journal of Environmental \& Agriculture Research, 3, 49-57. https://doi.org/10.25125/agriculture-journal-IJOEAR-AUG-2017-7

[21] University Service. http://www.univ-fhb.edu.ci

[22] ISO/DIS 14698-1 (ISO/DIS 14698-1 International Standard), Clean Room and Related Environment under Control of Bio-Contamination, 2003, 11.

[23] ISO-6578, International Organization for Standardization Amended ISO 6578: 2002/DAM. Microbiology of Food and Animal Feeding Stuffs-Horizontal Method for Detection of Salmonella spp. 2002.

[24] Rutala, W.A. and Weber, D.J. (1997) Water as a Reservoir of Nosocomial Pathogens. Infection Control \& Hospital Epidemiology, 18, 609-616. https://doi.org/10.2307/30141486

[25] Weber, D.J. and Rutala, W.A. (1997) Environmental Issues and Nosocomial Infec- 
tions. In: Wenzel, R.P., Ed., Prevention and Control of Nosocomial Infections, Williams \& Wilkins, Baltimore, 491-514.

[26] Munoz-Price, L.S., Birnbach, D.J., Lubarsky, D.A., et al. (2012) Decreasing Operating Room Environmental Pathogen Contamination through Improved Cleaning Practice. Infection Control \& Hospital Epidemiology, 33, 897-904. https://doi.org/10.1086/667381

[27] Kramer, A., Schwebke, I. and Kampf, G. (2006) How Long Do Nosocomial Pathogens Persist on Inanimate Surfaces? A Systematic Review. BMC Infectious Diseases, 6, Article No. 130. https://doi.org/10.1186/1471-2334-6-130

[28] Oie, S. and Kamiya, A. (1996) Survival of Methicillin-Resistant Staphylococcus Aureus (MRSA) on Naturally Contaminated Dry Mops. Journal of Hospital Infection, 34, 145-149.

[29] Wendt, C., Wiesenthal, B., Dietz, E. and Ruden H. (1998) Survival of VancomycinResistant and Vancomycin-Susceptible Enterococci on Dry Surfaces. Journal of Clinical Microbiology, 36, 3734-3736. https://doi.org/10.1128/JCM.36.12.3734-3736.1998

[30] Nataro, J.P. and Kaper, J.B. (1998) Diarrheagenic Escherichia coli. Clinical Microbiology Reviews, 11, 142-201. https://doi.org/10.1128/CMR.11.1.142

[31] Kaper, J.B., Nataro, J.P. and Mobley, H.L. (2004) Pathogenic Escherichia coli. Nature Reviews Microbiology, 2, 123-140. https://doi.org/10.1038/nrmicro818

[32] Jawad, A., Heritage, J., Snelling, A.M., Gascoyne-Binzi, D.M. and Hawkey, P.M. (1996) Influence of Relative Humidity and Suspending Menstrua on Survival of Acinetobacter spp. on Dry Surfaces. Journal of Clinical Microbiology, 34, 2881-2287. https://doi.org/10.1128/JCM.34.12.2881-2887.1996

[33] Alberti, C., Bouakline, A., Ribaud, P., Lacroix, C., Rousselot, P., Leblanc, T. and Derouin, F. (2001) Relationship between Environmental Fungal Contamination and the Incidence of Invasive Aspergillosis in Haematology Patients. Journal of Hospital Infection, 48, 198-206. https://doi.org/10.1053/jhin.2001.0998

[34] Phillips, M.S. and von Reyn, C.F. (2001) Nosocomial Infections Due to NonTuberculous Mycobacteria. Clinical Infectious Diseases, 33, 1363-1374.

[35] Stout, J.E. and Yu, V.L. (1997) Legionellosis. The New England Journal of Medicine, 337, 682-627.

[36] Yu, V.L. (1998) Resolving the Controversy on Environmental Cultures for Legionella: A Modest Proposal. Infection Control and Hospital Epidemiology, 19, 893-897. https://doi.org/10.1017/S0195941700092067

[37] Rhame, F. (1998) The Inanimate Environment. In: Benett, J. and Brachman, P., Eds., Hospital Infections, Lippincott-Raven, Philadelphia, 299-324.

[38] Marty, L., Flahault, A., Suarez, B., Caillon, J., Hill, C. and Andremont, A. (1993) Resistance to Methicillin and Virulence of Staphylococcus aureus strains in Bacteriemic Cancer Patients. Intensive Care Medicine, 19, 285-289. http://www.ncbi.nlm.nih.gov/pubmed/0008408938 